\title{
Enhanced cold-season warming in semi-arid regions
}

\author{
J. Huang, X. Guan, and F. Ji
}

Key Laboratory for Semi-Arid Climate Change of the Ministry of Education, College of Atmospheric Sciences, Lanzhou University, Lanzhou, 730000, China

Correspondence to: J. Huang (hjp@1zu.edu.cn)

Received: 6 January 2012 - Published in Atmos. Chem. Phys. Discuss.: 8 February 2012

Revised: 27 May 2012 - Accepted: 29 May 2012 - Published: 22 June 2012

\begin{abstract}
This study examined surface air temperature trends over global land from 1901-2009. It is found that the warming trend was particularly enhanced, in the boreal cold season (November to March) over semi-arid regions (with precipitation of $200-600 \mathrm{~mm} \mathrm{yr}^{-1}$ ) showing a temperature increase of $1.53^{\circ} \mathrm{C}$ as compared to the global annual mean temperature increase of $1.13^{\circ} \mathrm{C}$ over land. In mid-latitude semi-arid areas of Europe, Asia, and North America, temperatures in the cold season increased by 1.41 , 2.42 , and $1.5^{\circ} \mathrm{C}$, respectively. The semi-arid regions contribute $44.46 \%$ to global annual-mean land-surface temperature trend. The mid-latitude semi-arid regions in the Northern Hemisphere contribute by $27.0 \%$ of the total, with the midlatitude semi-arid areas in Europe, Asia, and North America accounting for $6.29 \%, 13.81 \%$, and $6.85 \%$, respectively. Such enhanced semi-arid warming (ESAW) imply drier and warmer trend of these regions.
\end{abstract}

\section{Introduction}

Large regional differences in surface air temperature trends have raised concerns as to whether regional trends may have biased estimations of large-scale temporal trends (Shukla and Mintz, 1982; Wu et al., 2011). Regional warming can be caused by various aspects, including changes of atmospheric circulations and sea surface temperature, interaction between land and atmosphere, and feedback from snow (Hu and Gao, 1994; Zhang et al., 2001; Liu et al., 2008; Huang et al., 2008). As noted by Wallace et al. $(1995,1996)$, greenhouse gases are not the only factor influencing temperature variability, dynamic causes also play important roles. Geographical patterns of warming trends over land are also strongly correlated with geographical patterns of industrial and socioeconomic development (McKitrick and Michaels, 2004; De Laat and Maurellis, 2006).

Semi-arid regions may be the most sensitive areas to global changes because of their fragile ecosystems (Rotenberg and Yakir, 2010). In these regions, potential evaporation exceeds precipitation on an annual averaged basis, and landscapes are characterized by dry climates, low vegetation cover, low nutrition content, and low capacity for water conservation in the soil (Zhai and Zhang, 2004). Both observation and modelling studies have indicated that an aridity trend is occurring and will occur most significantly in the semi-arid regions in terms of precipitation, soil moisture, and drought frequency as a result of global warming (Fu et al., 1999; Ma and $\mathrm{Fu}, 2007)$. For example, vertical stability and net energy in the semi-arid African Sahel have been analysed, and two distinct mechanisms have been found: one is anthropogenic warming indirectly changing continental climates, and the other is the increase in anthropogenic greenhouse gases, driving direct continental climate change (Giannini, 2010).

Here, we report on the relationship between warming and climatological mean precipitation. Our results suggest that dry regions are becoming warmer and that warming of semi-arid regions is particularly enhanced in the cold season. Trends in arid/semi-arid lands contribute significantly to global mean land surface air temperature trends.

\section{Datasets and analysis methodology}

We analysed data from the Climate Research Unit (monthly precipitation and monthly mean surface air temperature), version TS3.1, provided by the University of East Anglia. The data were for the period 1901 to 2009 (Mitchell and Jones, 2005) and had a resolution of $0.5^{\circ}$ by $0.5^{\circ}$. This gridded dataset is based on an archive of monthly mean 
temperatures provided by more than 4000 weather stations distributed around the world. The first version of the dataset is CRUTS1.0 which time period is from 1901 to 1995 and contains 7 variables. The dataset has 7 versions and the time period have extended to 2009. The number of variables has been increased from 7 to 10 .

In order to study the contributions of different precipitation regions to global surface temperature trends, the contribution rate was calculated by using the following procedure (Chandler and Scott, 2011):

1. To calculate the regional averaged temperature $\bar{T}_{k}$ of region $k$

$$
\bar{T}_{k}=\frac{\sum_{i=1}^{N_{k}} W_{k i} \cdot T_{k i}}{\sum_{i=1}^{N_{k}} W_{k i}}
$$

Where $N_{k}$ is the number of grids in region $k, T_{k i}$ is the temperature of grid $i$ in region $k$, and $W_{k i}=\cos \left(\theta_{i}\right.$. $\pi / 180.0)$, here $\theta_{i}$ is the latitude of the grid $i$. Equation (1) is used to calculate the averaged temperature for specific region. For the yearly averaged series of temperature, 109 regional averaged temperature values will be calculated for each type of precipitation region.

2. To calculate the contribution rate $\left(\mathrm{CR}_{k}\right)$ of region $k$

$$
\mathrm{CR}_{k}=\frac{a_{k} \cdot \sum_{i=1}^{N_{k}} W_{k i}}{A_{\mathrm{g}} \cdot \sum_{i=1}^{N_{\mathrm{g}}} W_{i}}
$$

Where $a_{k}$ is the trend of $\bar{T}_{k}$ for region $k, A_{\mathrm{g}}$ the trend of global land surface mean temperature, $N_{k}$ the number of grids in region $k, N_{\mathrm{g}}$ is the total number of all grids over global land. Contribution is one of the important factors to justify the warming extent to global warming. The contribution of different type of climate region can reflect the role of regional temperature warming to global warming.

\section{Results analysis}

Figure 1 presents the global distribution of 109-yr averaged annual precipitation, showing spatial variations in precipitation from less than $10 \mathrm{~mm} \mathrm{yr}^{-1}$ to a maximum of more than $1200 \mathrm{~mm} \mathrm{yr}^{-1}$. The climate of a region is determined by the long-term average, frequency, and extremes of several meteorological variables, most notably temperature and precipitation (Giddings et al., 2005). Although precipitation is related to surface temperature, the long-term mean precipitation is the simplest index for classifying climate regions. In Fig. 1,

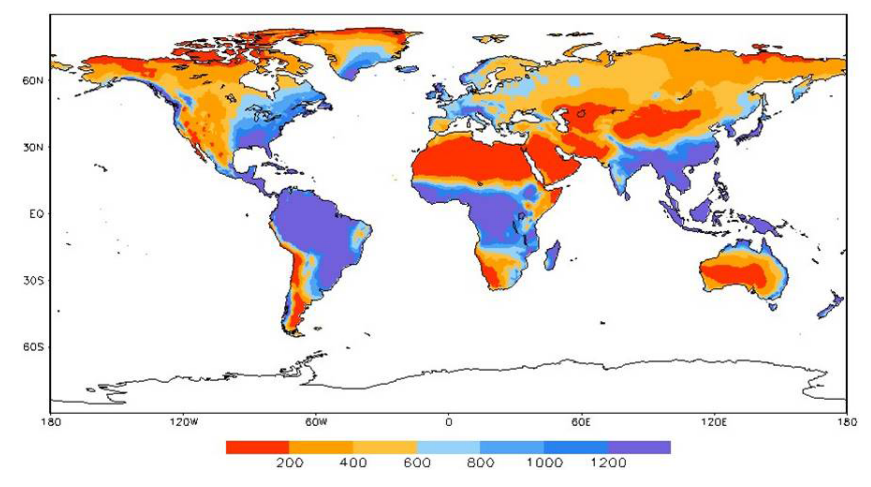

Fig. 1. Global distribution of annual mean precipitation from 1901 to $2009\left(\mathrm{~mm} \mathrm{yr}^{-1}\right)$.

the orange colour represents semi-arid regions, with precipitation ranging from 200 to $600 \mathrm{~mm} \mathrm{yr}^{-1}$. The semi-arid regions are defined as transition zones between arid and subhumid belts, characterized by low and restricted precipitation because of the inability of moisture-bearing winds to extend into and cool such regions. Semi-arid regions are also defined as areas where precipitation is less than potential evaporation, characterized by high temperatures $\left(30-45^{\circ} \mathrm{C}\right)$ in the hottest months. Mid-latitude semi-arid climates cover considerable parts of western North America and Central Asia. In North America, most of the semi-arid region is located in the west. In Central Asia, most of the semi-arid region is located in a transition area between arid regions and semi-wet regions. This climate generally has similar temperature characteristics as mid-latitude arid or desert regions. However, mid-latitude semi-arid regions receive slightly more precipitation than mid-latitude arid regions.

Figure 2 shows the global distribution of the temperature trends for the annual, cold season, and warm season. Generally, the temperature trend is positive in most of the mid-high latitude area, although there are small dark blue patches with small negative trends in south-eastern North America, western South America, northern Australia, and several small domains in Asia and Africa. The temperature trend over continents is largely positive and is particularly pronounced over Asia and North America. The central regions of increase are mid-high latitude areas, including the semi-arid regions of North America and Central Asia. The pattern for the cold season is quite different from that of the warm season. In the cold season, the strongest warming occurs in the midhigh latitudes of the Northern Hemisphere. In contrast, an enhanced strong warming does not occur in these areas in the warm season, indicating that surface warming is not uniform in the different seasons. The rate of temperature increase in the warm season is weak compared with the rate in the cold season, especially in Asia; the degree of temperature variability is smaller than in North America. The warming trend in Central Asia in the cold season is much more obvious than in other regions globally. The pattern of warming in Central 

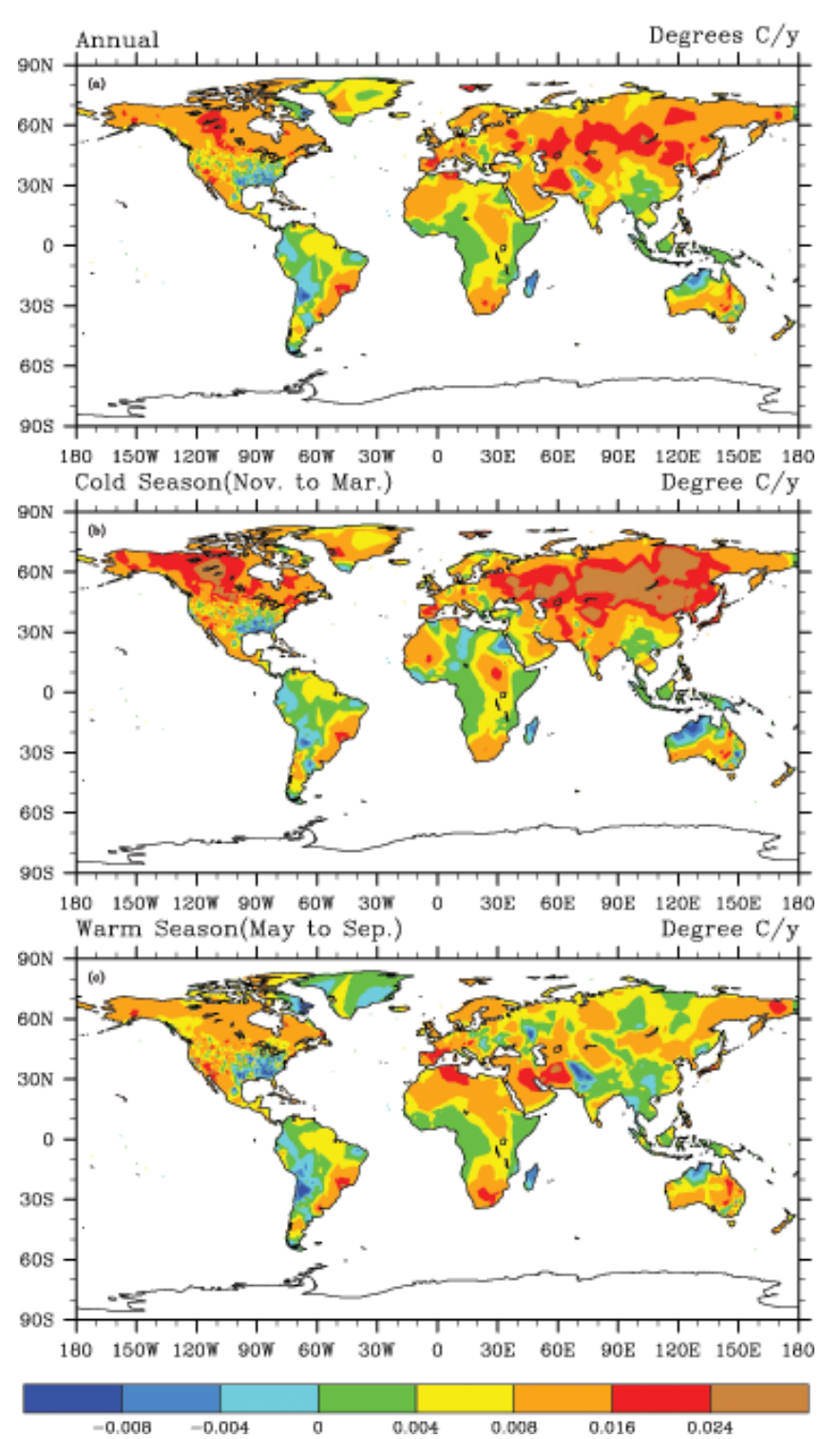

Fig. 2. Global distribution of linear land surface temperature trend in the period of 1901-2009 for (a) Annual, (b) Cold season (November to March), and (c) Warm season (May to September) (unit: ${ }^{\circ} \mathrm{C} \mathrm{yr}^{-1}$ ).

Asia in the warm season is not only different from that in the cold season, but is also weaker than that in the cold season in scope and intensity.

Figure 3 presents regionally averaged annual mean landsurface air temperature trends as a function of the climatological mean precipitation. The climatological mean precipitation is the annual mean precipitation for the period 1901 to 2009. Although precipitation and temperature are the two fundamental variables used in describing climate change, the climatological mean precipitation can be used to classify climate regions. Figure 3 shows that surface temperature does not increase everywhere uniformly but as a first-order ap-

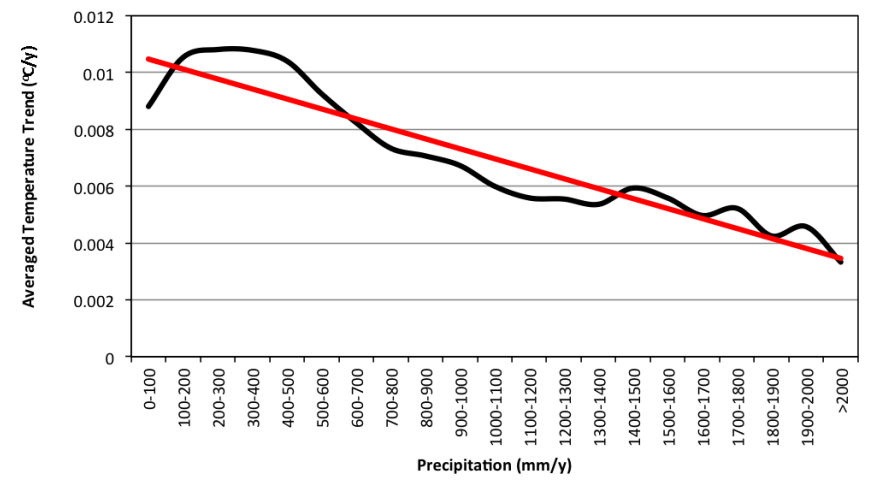

Fig. 3. The annual and regional averaged land surface linear temperature trend as function of climatological mean precipitation. The precipitation interval is $100 \mathrm{~mm} \mathrm{yr}^{-1}$.

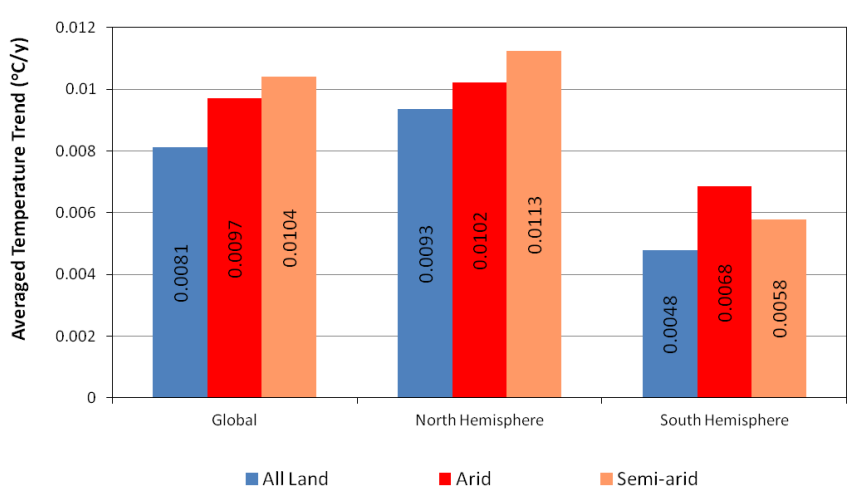

Fig. 4. The averaged temperature trend for arid region, semi-arid region and all land over Global, Northern Hemisphere (NH), and Southern Hemisphere (SH).

proximation, the temperature trend decreases monotonically as annual climatological mean precipitation increases. This indicates that drier land has become warmer. Increased temperature would lead to larger evapotranspiration causing dry land even drier, and thus deteriorating ecological systems there. Warming is particularly enhanced in semi-arid regions, where warming has increased faster than in all other regions.

Figure 4 compares regionally averaged temperature trends for the arid, semi-arid, and whole land areas of the world, the Northern Hemisphere, and the Southern Hemisphere. The figure indicates the warming amplitude in different climate regions. From visual inspection, the surface temperature in arid regions is increasing slowly than in semi-arid regions in the three selected areas except South Hemisphere. The variability in semi-arid regions is distinguishable from that in other regions. Furthermore, warming in semi-arid regions of the Northern Hemisphere is increasing faster than that in the Southern Hemisphere. The warming trend over arid regions in the Northern Hemisphere is more obvious than in the Southern Hemisphere.

Figure 5 compares the regionally averaged land surface linear temperature trend as a function of climatological mean 


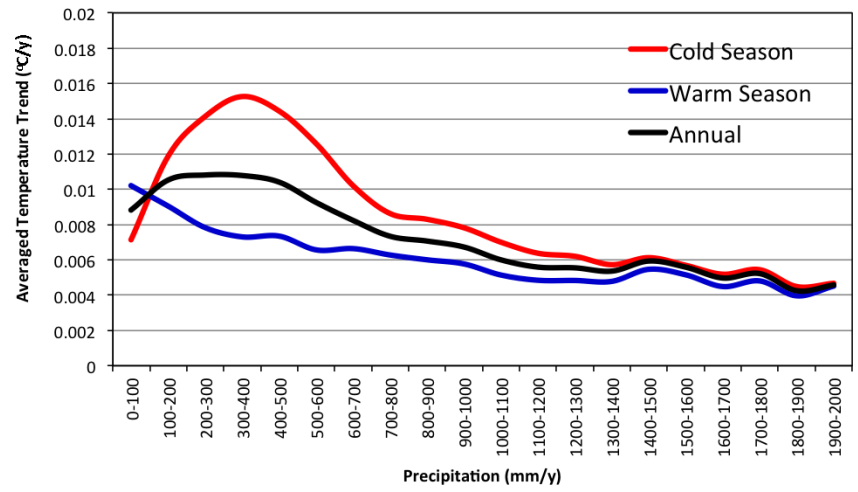

Fig. 5. Comparison of the regional averaged land surface linear temperature trend as function of climatological mean precipitation for annual, cold season and warm season of global. The precipitation interval is $100 \mathrm{~mm} \mathrm{yr}^{-1}$.

precipitation for the annual, the cold season, and the warm season. There is an obvious increase in temperature in the semi-arid regions with a warming peak around the rainfall range of $300-400 \mathrm{~mm} \mathrm{yr}^{-1}$ in the cold season; the warming trend in the cold season is more than double of the trend in the warm season. This suggests that semi-arid warming is enhanced or accelerated in the cold season, indicating that the temperature variability in semi-arid regions in the cold season is more sensitive to climate change than the temperature variability in other regions. For wet regions (rainfall $>1000 \mathrm{~mm} \mathrm{yr}^{-1}$ ), the warming trend is not significantly different between the cold and warm seasons.

Figure 6 presents the temperature trend over $20-60^{\circ} \mathrm{N}$ for the annual, cold season, and warm season means. This figure also shows the enhanced warming in the cold season over arid/semi-arid regions. The rate of temperature increase is much higher in the cold season than in the warm season. For example, the warming rate $\left(0.0194^{\circ} \mathrm{C} \mathrm{yr}^{-1}\right)$ in regions of approximately $300-400 \mathrm{~mm} \mathrm{yr}^{-1}$ rainfall is 2.4 times larger than that in the warm season. To compare with Fig. 5, Fig. 6 reveals that the warming trend over semi-arid regions within $20-60^{\circ} \mathrm{N}$ is higher than the global trend.

Table 1 compares the warming amplitudes of temperatures for different semi-arid region and seasons, showing that warming have been most significant in semi-arid regions. Annual, cold season, and warm season temperatures increased by $1.33,1.89$, and $0.85^{\circ} \mathrm{C}$ over the mid-high latitudes of North Hemisphere in the period from 1901 to 2009, respectively. In the same period, the cold season temperature in mid-latitude semi-arid areas in Europe, Asia, and North America increased by $1.41,2.42$, and $1.50^{\circ} \mathrm{C}$, respectively, with semi-arid of Asia showing the most warming. In the warm season, mid-latitude semi-arid areas in Europe, Asia, and North America warmed by $0.95,0.68$, and $1.05^{\circ} \mathrm{C}$, respectively, during the study period. The temperature in semiarid regions of Asia is increasing more than that of North

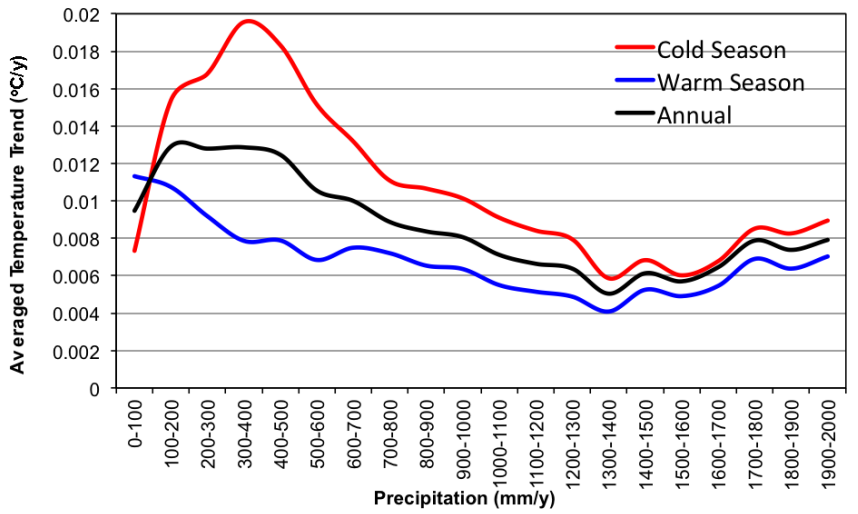

Fig. 6. Same as Fig. 5 but for $20-60^{\circ} \mathrm{N}$.

Table 1. The warming amplitude of temperature over semi-arid region for different areas, where Global is defined as global land, $\mathrm{NH}$ is the Northern Hemisphere, North America is the region of 20$60^{\circ} \mathrm{N},-180 \sim-17^{\circ} \mathrm{W}$, Europe is the region of $20-60^{\circ} \mathrm{N},-17^{\circ} \mathrm{W}-$ $60^{\circ} \mathrm{E}$, and Asia is the region of $20-60^{\circ} \mathrm{N}, 60-180^{\circ} \mathrm{E}$ (unit: ${ }^{\circ} \mathrm{C}$ ).

\begin{tabular}{lllllll}
\hline & Global & NH & $\begin{array}{l}20- \\
60^{\circ} \mathrm{N}\end{array}$ & Europe & Asia & $\begin{array}{l}\text { North } \\
\text { America }\end{array}$ \\
\hline Annual & 1.13 & 1.23 & 1.33 & 1.18 & 1.51 & 1.19 \\
Cold Season & 1.53 & 1.72 & 1.89 & 1.41 & 2.42 & 1.50 \\
Warm Season & 0.79 & 0.81 & 0.85 & 0.95 & 0.68 & 1.06 \\
\hline
\end{tabular}

America in the cold season, whereas warming in the warm season is more obvious in North America than in Asia.

Figures 7 and 8 show the contributions of surface temperature trends in different precipitation regions to the global trend for the annual and cold season means. The figure clearly shows the remarkable contributions of different rainfall regions to the global mean trend. The semi-arid regions play a dominant role in global warming and account for nearly half of continental warming, with considerably weaker temperature trends over semi-wet and wet regions. Semi-arid regions make an even greater contribution to global warming in the cold season (Fig. 8), and the contribution figures for the cold season show particularly distinct differences between semi-arid and semi-wet regions. These results are also shown in Table 2, which indicates that the Asia semi-arid region made the biggest contribution to global warming. The semi-arid regions in Europe, Asia, and North America contributed $6.29 \%, 13.81 \%$, and $6.85 \%$ of the warming in global surface temperature, respectively. The contributions of arid, semi-wet, and wet regions were lower.

\section{Summary}

The increase in global-mean surface temperature is expected to lead to increased evapotranspiration over land and to affect the global water cycle, with climatologically wet regions becoming wetter, dry regions becoming drier, and rainfall 


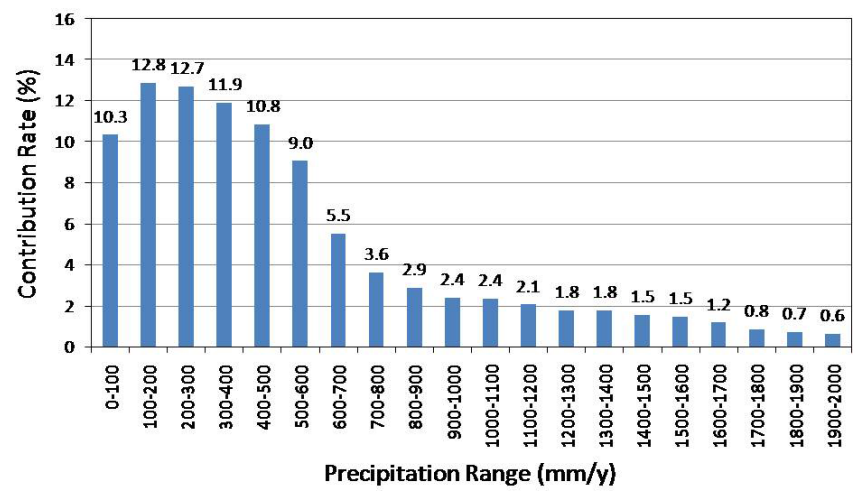

Fig. 7. The regional contribution of land-surface linear air temperature trend to global as function of climatological mean precipitation. The precipitation interval is $100 \mathrm{~mm} \mathrm{yr}^{-1}$. The result of the regions which climatological mean precipitation is larger than $2000 \mathrm{~mm}$ are omitted due to smaller contribution rate.

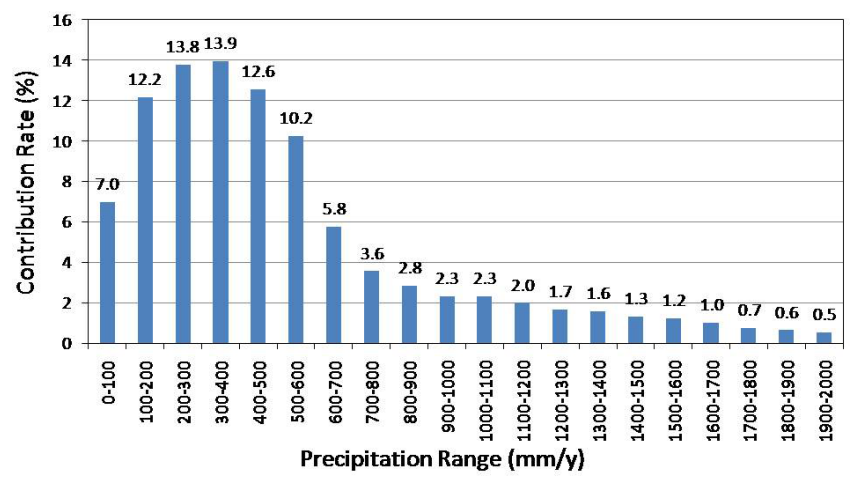

Fig. 8. Same as Fig. 7 but for cold season (November to March).

events becoming more intense (Trenberth et al., 2003; Neelin et al., 2003; Meehl et al., 2007). Our results suggest that dry regions are becoming warmer, especially in the cold season, over semi-arid regions. We found a particularly large warming trend in semi-arid regions (annual rainfall totalling 200$600 \mathrm{~mm} \mathrm{yr}^{-1}$ ), where the annual, cold season, and warm season mean temperatures increased by $1.13,1.53$, and $0.79^{\circ} \mathrm{C}$, respectively, over the period from 1901 to 2009. In the same period, the cold season temperatures in semi-arid areas of mid-latitude Europe, Asia, and North America increased by $1.41,2.42$, and $1.50{ }^{\circ} \mathrm{C}$, respectively. The semi-arid regions contribute $44.46 \%$ of the global land-surface air temperature trends. Such enhanced semi-arid warming (ESAW) may be caused by various factors including circulation dynamical adjustment and SST anomalies, land surface processes, snow/frozen ground, and regional human activity (Fig. 9). The primary factors on the enhanced warming in semi-arid areas, however, may differ in different regions.
Table 2. Contribution of different mid-latitude region of landsurface temperature trend to global trend, where Europe is defined as the region of $20-60^{\circ} \mathrm{N},-17^{\circ} \mathrm{W}-60^{\circ} \mathrm{E}$, Asia is the region of $20-60^{\circ} \mathrm{N}, 60-180^{\circ} \mathrm{E}$, North America is the region of $20-60^{\circ} \mathrm{N}$, $-180 \sim-17^{\circ} \mathrm{W}$ (unit: \%).

\begin{tabular}{llll}
\hline & Europe & Asia & North America \\
\hline Arid & 8.76 & 5.65 & 0.64 \\
Semi-arid & 6.29 & 13.81 & 6.85 \\
Semi-wet & 3.23 & 2.48 & 3.54 \\
Wet & 0.73 & 3.11 & 2.20 \\
\hline
\end{tabular}

\section{Discussions}

Fu et al. (2006) reported widening of the tropical in the period 1979-2005 and estimated that the tropical belt had widened by about $2^{\circ}$ of latitude. Such widening of the tropics would result in shifts in precipitation and temperature patterns (Seidel et al., 2007) and modify circulation patterns. Recently, advances in modelling have shown that a robust characteristic of anthropogenic climate change is a pole-ward expansion of the Hadley cells and shifting of the pattern of precipitation minus evaporation $(P-E)$ and storm tracks (Solomon et al., 2009; Seager et al., 2007), resulting in a pattern of drying over much of the already-dry subtropics in a warmer world (15-40 latitude in each hemisphere) (Held and Soden, 2006). Gong et al. (2001) attributed the enhanced surface air warming in the boreal cold season over the $\mathrm{NH}$ mid-high latitude land to the changes of atmospheric circulation based on observational data analyses. However, dynamic adjustment does not explain the significant difference between warming trends in the semi-arid regions of Europe, Asia, and North America.

Recent atmospheric modelling using the long-term history of global SST has supported the claim that oceans play a role in controlling the climate of the Sahel, a typical semiarid region (Giannini et al., 2003; Bader and Latif, 2003; Lu and Delworth, 2005; Hoerling et al., 2006). Climate change over arid/semi-arid regions in Asia is also greatly affected by SST variability. During drought periods, the SST anomaly is positive in the tropical eastern Pacific but negative in the extratropical North Pacific, indicating a warm phase of Pacific decadal oscillation, and vice versa (Fu et al., 2008). Rainfall patterns and associated summer monsoon circulation exhibited a decadal change around the late 1970s over East Asia, influenced by warming in tropical SSTs. Recent studies ( $\mathrm{Li}$ et al., 2010) also revealed that historical droughts in North America, West Africa, and East Asia were linked to tropical SST variation. El Niño-like SST warming in the Pacific caused shifts in the warmest SSTs in the Pacific, causing drought in East China (Dai, 2011). Ma and Fu (2003), Ma and Shao (2006) and Ma (2007) found that the drought events that happened over arid and semi-arid areas of Asia have a strong relationship with the variability of SST in the Pacific. 


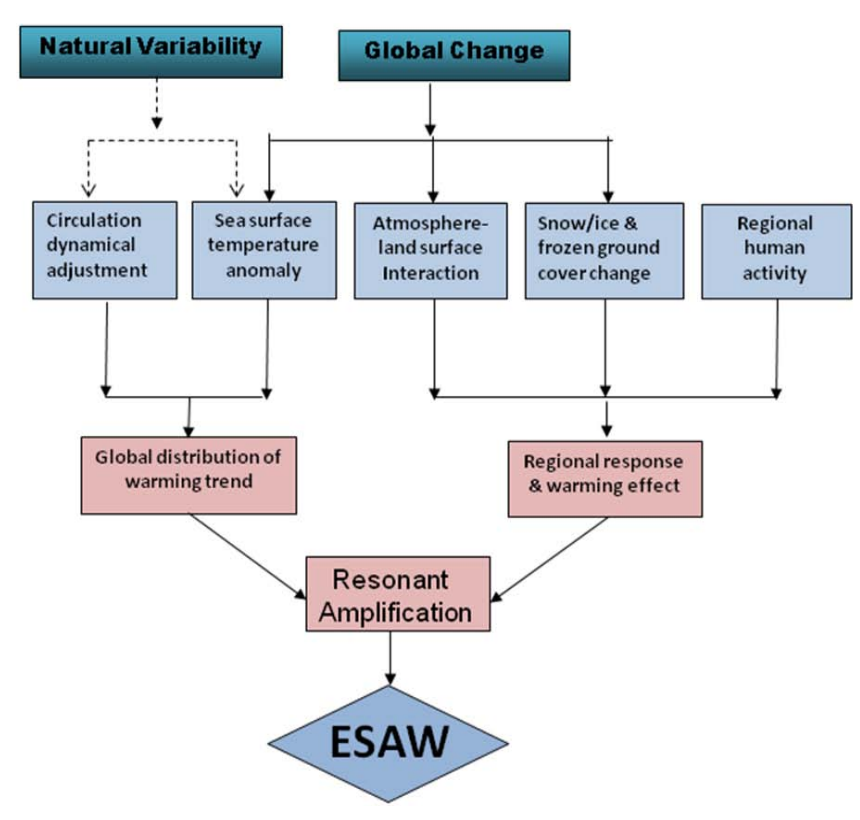

Fig. 9. Schematic diagram of enhanced semi-arid warming (ESAW).

The feedback system of surface albedo, desertification, and biogeophysics may have partially caused the significant warming over semi-arid regions (Charney, 1975; Charney et al., 1977). The drying of sandy or rocky soil by higher temperatures would increase the surface albedo, thus reflecting more solar radiation back to space. The net result is that semiarid regions are a radiation sink of heat relative to surrounding regions. Some observational analyses suggest that desertification over the past several decades has contributed negative forcing at the Earth's surface equivalent to $\sim 20 \%$ of the global anthropogenic $\mathrm{CO}_{2}$ effect over the same period, moderating warming trends (Rotenberg and Yakir, 2010). Shuman et al. (2011) found that boreal forests in the Northern Hemisphere, particularly those in Siberia, may have a strong effect on the Earth's climate through changes in the dominant vegetation and associated regional surface albedo. The warmer climate will likely ultimately convert Siberia's deciduous larch (Larix spp) to evergreen conifer forests, and thus decrease regional surface albedo. Shuman et al. (2011) found that a conversion from larch to evergreen stands in low-diversity regions of southern Siberia would generate a local positive radiative forcing of $2.6 \mathrm{~W} \mathrm{~m}^{-2}$. This radiative heating would reinforce the warming projected to occur in the area under climate change.

Snow cover in the Northern Hemisphere, as measured from satellites, has declined substantially in the past $30 \mathrm{yr}$, particularly from early spring through summer (Zhai and Zhou, 1997). The reduction of snow cover may cause the surface temperature to increase in the cold season. The thickness of seasonally frozen ground has decreased in response to winter warming (Lemke et al., 2007). On the other hand, both dust and biomass burning aerosols may impact the surface albedo when deposited on snow; soot in particular has large impacts on absorption of radiation (Qian et al., 2011). Flanner et al. (2009) applied a range of models and observations to explore the impacts of these processes on springtime climate and found that equilibrium climate experiments suggest that fossil fuel and biofuel emissions of black carbon plus organic matter $(\mathrm{BC}+\mathrm{OM})$ induce $95 \%$ as much as springtime snow cover loss over Eurasia as anthropogenic carbon dioxide, a consequence of strong snow feedback and large $\mathrm{BC}+\mathrm{OM}$ emissions from Asia. Qian et al. (2009) reported that $\mathrm{BC}$ mixed with snow resulted in a $0.5-3 \%$ perturbation in the snow albedo and that the snow skin (2-m air) temperature increased by $0.2-1.4^{\circ} \mathrm{C}\left(0.1-1.0^{\circ} \mathrm{C}\right)$ over the majority of snow-covered areas in the western US during late winter to early spring.

Such anthropological effects are particularly acute in the fragile ecosystems of arid and semi-arid regions. For example, agricultural activity in semi-arid areas generates dust (Mulitza et al., 2010) demonstrated a very large increase in dust emission and deposition in the Sahel coinciding with the development of agriculture in the area. Similar results were found in semi-arid regions in China (Huang et al., 2010). Multiza et al. (2010) found that local anthropogenic dust aerosols associated with human activities such as agriculture and industrial activity accounted for $43 \%$ of the total dust burden in the atmosphere. Analysis of satellite observations indicated that, on average, both naturally transported and local anthropogenic dust aerosols can significantly reduce water cloud particle size, optical depth, and liquid water path (Huang et al., 2006a, b, 2010). These results suggest that dust aerosols warm the clouds and increase evaporation of cloud droplets, further reducing cloud water path via the so-called semi-direct effect. Such semi-direct effects may play an important role in cloud development and act to exacerbate drought conditions over semi-arid areas of northwest China (Huang et al., 2006a, b, 2010; Su et al., 2008; Wang et al., 2010). Change in rainfall over East Asia has been attributed to human-induced air pollution (Menon et al., 2002) and warming of tropical SSTs (Li et al., 2010). Rain increases with aerosol concentration in deep clouds that have a high liquid-water content, but declines in clouds that have a low liquid-water content, which was confirmed by simulations with a cloud-resolving model confirm (Li et al., 2011). Human activity has also induced land cover changes over transitional areas, bringing about land degradation. As one of the most sensitive areas to global warming, semi-arid regions are also the most vulnerable to human perturbations. It reported that changes in land cover may lead to significant changes in the East Asian monsoon, based on a pair of numerical experiments (Fu and Yuan, 2001; Fu, 2003).

All the factors discussed above contribute to the enhanced warming found over semi-arid regions (Fig. 9). The global pattern of surface temperature trends and of warming in dry regions may be dominated by circulation dynamical 
adjustment and SST anomalies due to greenhouse gas forcing. Accelerated warming in semi-arid regions may also be attributable to local land surface processes, changes in snow and frozen soil cover, and human activity. Further studies are needed to clarify the contributions of these factors.

It has been discussed that aridification in South-Eastern Europe (Kertész and Mika, 1999) and aridity trend in northern China (Fu et al., 2008).

Acknowledgements. This work was jointly supported by the National Basic Research Program of China (2012CB955301) and National Science Foundation of China under grant 40725015, the Cultivation Fund of the Key Scientific and Technical Innovation Project Ministry of Education of China (No. 708088), and the Program for Changjiang Scholars and Innovative Research Team in University (IRT1018).

Edited by: Q. Fu

\section{References}

Bader, J. and Latif, M.: The impact of decadal-scale Indian Ocean sea surface temperature anomalies on Sahelian rainfall and the North Atlantic Oscillation, Geophys. Res. Lett, 30, 2169, doi:10.1029/2003GL018426, 2003.

Chandler, R. E. and Scott, E. M.: Statistical Methods for Trend Detection and Analysis in the Environmental Sciences, Wiley, 2011.

Charney, J. G.: Dynamics of deserts and drought in the Sahel, Q. J. Roy Meteor. Soc., 101, 193-202, 1975.

Charney, J., Quirk, W. J., Chow, S. H., and Kornfield, J.: A comparative study of the effects of albedo change on drought in semi-arid regions, J. Atmos. Sci. 34, 1366-1385, 1977.

Dai, A.: Drought under global warming: a review, Wiley Interdisciplinary Reviews: Climate Change, 2, 45-65, 2011.

De Laat, A. and Maurellis, A.: Evidence for influence of anthropogenic surface processes on lower tropospheric and surface temperature trends, Int. J. Climatol., 26, 897-913, 2006.

Flanner, M. G., Zender, C. S., Hess, P. G., Mahowald, N. M., Painter, T. H., Ramanathan, V., and Rasch, P. J.: Springtime warming and reduced snow cover from carbonaceous particles, Atmos. Chem. Phys., 9, 2481-2497, doi:10.5194/acp-9-24812009, 2009.

Fu, C.: Potential impacts of human-induced land cover change on East Asia monsoon, Global Planet. Change, 37, 219-229, 2003.

$\mathrm{Fu}, \mathrm{C}$. and Yuan, H.: An virtual numerical experiment to understand the impacts of recovering natural vegetation on the summer climate and environmental conditions in East Asia, Chinese Sci. Bull., 46, 1199-1203, 2001.

Fu, C., Diaz, H. F., Dong, D., and Fletcher, J. O.: Changes in atmospheric circulation over Northern Hemisphere oceans associated with the rapid warming of the 1920s, Int. J. Climatol., 19, 581606, 1999.

Fu, C., Jiang, Z., Guan, Z., He, J., and Xu, Z.: Regional Climate Studies of China, Berlin, Springer, 1, 156-159, 2008.

Fu, Q., Johanson, C. M., Wallace, J. M., and Reichler, T.: Enhanced Mid-Latitude Tropospheric Warming in Satellite Measurements, Science, 312, 1179, doi:10.1126/science.1125566, 2006.
Giannini, A.: Mechanisms of climate change in the semiarid African Sahel: the local view, J. Climate, 23, 743-756, 2010.

Giannini, A., Saravanan, R., and Chang, P.: Oceanic forcing of Sahel rainfall on interannual to interdecadal time scales, Science, 302, 1027-1030, 2003.

Giddings, L., Soto, M., Rutherford, B., and Maarouf, A.: Standardized precipitation index zones for México, Atmosfera, 18, 33-56, 2005.

Gong, D., Zhou, T., and Wang, S.: Advance in the studies on north atlantic oscillation (NAO), Advance in Earth Sciences, 16, 413420, 2001 (in Chinese).

Held, I. M. and Soden, B. J.: Robust responses of the hydrological cycle to global warming, J. Climate, 19, 5686-5699, 2006.

Hoerling, M., Hurrell, J., Eischeid, J., and Phillips, A.: Detection and Attribution of Twentieth-Century Northern and Southern African Rainfall Change, J. Climate, 19, 3989-4008, 2006.

$\mathrm{Hu}$, Y. and Gao, Y.: Some new understandings of processes at the land surface in arid area from the HEIFE, Acta Meteorol. Sin., 52, 285-296, 1994.

Huang, J., Lin, B., Minnis, P., Wang, T., Wang, X., Hu, Y., Yi, Y., and Ayers, J. K.: Satellite-based assessment of possible dust aerosols semi-direct effect on cloud water path over East Asia, Geophys. Res. Lett, 33, L19802, doi:10.1029/2006GL026561, $2006 \mathrm{a}$.

Huang, J., Minnis, P., Lin, B., Wang, T., Yi, Y., Hu, Y., SunMack, S., and Ayers, K.: Possible influences of Asian dust aerosols on cloud properties and radiative forcing observed from MODIS and CERES, Geophys. Res. Lett., 33, L06824, doi:10.1029/2005GL024724, 2006b.

Huang, J., Zhang, W., Zuo, J., Bi, J., Shi, J., Wang, X., Chang, Z., Huang, Z., Yang, S., and Zhang, B.: An overview of the semi-arid climate and environment research observatory over the Loess Plateau, Adv. Atmos. Sci., 25, 906-921, 2008.

Huang, J., Minnis, P., Yan, H., Yi, Y., Chen, B., Zhang, L., and Ayers, J. K.: Dust aerosol effect on semi-arid climate over Northwest China detected from A-Train satellite measurements, Atmos. Chem. Phys., 10, 6863-6872, doi:10.5194/acp-10-68632010, 2010.

Kertész, Á. and Mika, J. : Aridification - climate change in SouthEastern Europe, Phys. Chem. Earth, 24, 913-920, 1999.

Lemke, P., Ren, J., Alley, R. B., Allison, I., Carrasco, J., Flato, G., Fujii, Y., Kaser, G., Mote, P., Thomas, R. H., and Zhang, T.: Observations: Changes in Snow, Ice and Frozen Ground, in: Climate change: the physical science basis. Contribution of Working Group 1 to the fourth assessment report of the Intergovernmental Panel on Climate Change, edited by: Solomon, S., Qin, D., Manning, M., Chen, Z., Marquis, M., Averyt, K. B., Tignor, M., and Miller, H. L., Cambridge University Press, Cambridge, 2007.

Li, H., Dai, A., Zhou, T., and Lu, J.: Responses of East Asian summer monsoon to historical SST and atmospheric forcing during 1950-2000, Clim. Dynam., 34, 501-514, 2010.

Li, Z., Niu, F., Fan, J., Liu, Y., Rosenfeld, D., and Ding, Y.: The long-term impacts of aerosols on the vertical development of clouds and precipitation, Nat. Geosci., 4, 888-894, doi:10.1038/NGEO1313, 2011.

Liu, H., Wang, B., and Fu, C.: Relationships between surface albedo, soil thermal parameters and soil moisture in the semiarid area of Tongyu, northeastern China, Adv. Atmos. Sci., 25, 757-764, 2008. 
Lu, J. and Delworth, T. L.: Oceanic forcing of the late 20th century Sahel drought, Geophys. Res. Lett, 32, L22706, doi:10.1029/2005GL023316, 2005.

Ma, Z.: The interdecadal trend and shift of dry/wet over the central part of North China and their relationship to the Pacific Decadal Oscillation (PDO), Chinese Sci. Bull., 52, 2130-2139, 2007.

$\mathrm{Ma}, \mathrm{Z}$. and Fu, C.: Interannual characteristics of the surface hydrological variables over the arid and semi-arid areas of northern China, Global Planet. Change, 37, 189-200, 2003.

$\mathrm{Ma}, \mathrm{Z}$. and $\mathrm{Fu}, \mathrm{C}$. : Evidences of drying trend in the global during the later half of 20th century and their relationship with largescale climate background, Sci. China Ser. D., 37, 222-233, 2007 (in Chinese).

Ma, Z. and Shao, L.: Relationship Between Dry/Wet Variation and the Pacific Decade Oscillation (PDO) in Northern China During the Last 100 Years, Chinese Journal of Atmospheric Science, 30, 464-474, doi:10.3878/j.issn.1006-9895.2006.03.10, 2006 (in Chinese).

McKitrick, R. and Michaels, P. J.: Are temperature trends affected by economic activity? Reply to Benestad (2004), Clim. Res., 27, 175-176, 2004.

Meehl, G., Stocker, T. F., Collins, W. D., Friedlingstein, P., Gaye, A. T., Gregory, J. M., Kitoh, A., Knutti, R., Murphy, J. M., Noda, A., Raper, S. C. B., Watterson, I. G., Weaver, A. J., and Zhao, Z. C.: Global climate projections, in: Climate change: the physical science basis. Contribution of Working Group 1 to the fourth assessment report of the Intergovernmental Panel on Climate Change, edited by: Solomon, S., Qin, D., Manning, M., Chen, Z., Marquis, M., Averyt, K. B., Tignor, M., and Mille, H. L., Cambridge University Press, Cambridge, 2007.

Menon, S., Hansen, J., Nazarenko, L., and Luo, Y.: Climate effects of black carbon aerosols in China and India, Science, 297, 22502253, doi:10.1126/science.1075159, 2002.

Mitchell, T. D. and Jones, P. D.: An improved method of constructing a database of monthly climate observations and associated high-resolution grids, Int. J. Climatol., 25, 693-712, 2005.

Mulitza, S., Heslop, D., Pittauerova, D., Fischer, H. W., Meyer, I., Stuut, J. B., Zabel, M., Mollenhauer, G., Collins, J. A., and Kuhnert, H.: Increase in African dust flux at the onset of commercial agriculture in the Sahel region, Nature, 466, 226-228, 2010.

Neelin, J., Chou, C., and Su, H.: Tropical drought regions in global warming and El Nino teleconnections, Geophys. Res. Lett., 30, 2275, doi:10.1029/2003GL018625, 2003.

Qian, Y., Gustafson Jr., W. I., Leung, L. R., and Ghan, S. J.: Effects of soot-induced snow albedo change on snowpack and hydrological cycle in western United States based on Weather Research and Forecasting chemistry and regional climate simulations, J. Geophys. Res., 114, D03108, doi:10.1029/2008JD011039, 2009.

Qian, Y., Flanner, M. G., Leung, L. R., and Wang, W.: Sensitivity studies on the impacts of Tibetan Plateau snowpack pollution on the Asian hydrological cycle and monsoon climate, Atmos. Chem. Phys., 11, 1929-1948, doi:10.5194/acp-11-19292011, 2011 .
Rotenberg, E. and Yakir, D.: Contribution of semi-arid forests to the climate system, Science, 327, 451-454, 2010.

Seager, R., Ting, M., Held, I., Kushnir, Y., Lu, J., Vecchi, G., Huang, H., Harnik, N., Leetmaa, A., and Lau, N., Li, C., Velez, J., and Naik, N. : Model projections of an imminent transition to a more arid climate in southwestern North America, Science, 316, 11811184, doi:10.1126/science.1139601, 2007.

Seidel, D. J., Fu, Q., RanDel, W. J., and Reichle, R. T. S. J.: Widening of the tropical belt in a changing climate, Nat. Geosci., 1, 21-24, 2007.

Shukla, J. and Mintz, Y.: Influence of land-surface evapotranspiration on the earth's climate, Science, 215, 1498-1501, 1982.

Shuman, J. K., Shugart, H. H., and O'halloran, T. L.: Sensitivity of Siberian larch forests to climate change, Global Change Bio., 17, 2370-2384, 2011.

Solomon, S., Plattner, G. K., Knutti, R., and Friedlingstein, P.: Irreversible climate change due to carbon dioxide emissions, P. Natl. Acad. Sci. USA, 106, 1704-1709, 2009.

Su, J., Huang, J., Fu, Q., Minnis, P., Ge, J., and Bi, J.: Estimation of Asian dust aerosol effect on cloud radiation forcing using FuLiou radiative model and CERES measurements, Atmos. Chem. Phys., 8, 2763-2771, doi:10.5194/acp-8-2763-2008, 2008.

Trenberth, K. E., Dai, A., Rasmussen, R. M., and Parsons, D. B.: The changing character of precipitation, B. Am. Meteorol. Soc., 84, 1205-1218, 2003.

Wallace, J. M., Zhang, Y., and Renwick, J. A.: Dynamic contribution to hemispheric mean temperature trends, Science, 270, 780783, 1995.

Wallace, J. M., Zhang, Y., and Bajuk, L.: Interpretation of interdecadal trends in Northern Hemisphere surface air temperature, J. Climate, 9, 249-259, 1996.

Wang, W., Huang, J., Minnis, P., Hu, Y., Li, J., Huang, Z., Ayers, J., and Wang, T.: Dusty cloud properties and radiative forcing over dust source and downwind regions derived from A-Train data during the Pacific Dust Experiment, J. Geophys. Res, 115, D00H35, doi:10.1029/2010JD014109, 2010.

Wu, Z., Huang, N., Wallace, J., Smoliak, B., and Chen, X.: On the time-varying trend in global-mean surface temperature, Clim Dynam., 37, 759-773, doi:10.1007/s00382-011-1128-8, 2011.

Zhai, P. and Zhang, G.: Climate change and meteorological disasters, Science \& Technology Review, 7, 11-14, 2004 (in Chinese)

Zhai, P. and Zhou, Q.: The change of northern hemisphere snow cover and its impact on summer rainfalls in China, Quarterly Journal of Applied Meteorology, 8, 231-235, 1997 (in Chinese).

Zhang, Q., Wei, G., and Huang, R.: Observation and study of atmospheric drag coefficients in Dunhuang, Sci. China Ser. D., 31, 783-792, 2001 (in Chinese). 